\title{
PENGELOLAAN SUPERVISI KLINIS PENGAWAS , PENDEKATAN “PAS” BAGI PENINGKATAN KINERJA GURU TIPE GURU (ANALYTICAL OBSERVER)
}

\author{
NUR SA'IDU \\ Pengawas Madrasah Kementerian Agama Kab. Semarang \\ Email : nuripurbosari68@gmail.com
}

\begin{abstract}
ABSTRAK
Penelitian ini mendeskripsikan tentang supervisi klinis pengawas dengan pendekatan Persuasi, Analisis, Solusi (PAS) di masa pandemi covid-19 dalam pemecahan masalah guru Tipe (Analytical Observer) di Madrasah binaan Kecamatan Bringin Kabupaten Semarang Jawa Tengah. Jenis Penelitian kualitatif dengan sifat deskriptif dipergunakan dalam penelitian ini . Pengumpulan data dilakukan melalui wawancara mendalam, observasi, dokumentasi dan kuesioner (survey). Pemeriksaan data menggunakan teknik triangulasi untuk memastikan bahwa data memenuhi kredibilitas. Sedangkan data dianalisis dengan mempergunakan model Miles dan Huberman yang terdiri dari reduksi data, bagaimana data disajikan dan apa kesimpulannya. Hasil penelitian menggambarkan bahwa implementasi supervisi klinis masih dapat dilakukan di tengah pandemi covid-19 dengan memodifikasi teknik supervisi klinis. Dan pada akhirnya, supervisi klinis yang dilakukan dapat memberikan bimbingan dan motivasi bagi guru untuk memecahkan masalah kinerja dalam pembelajaran. Pendekatan PAS supervisi klinis pengawas mengedepankan proses kolaborasi kemitraan bukan mencari cari kesalahan guru, tetapi melalui diagnosis dan analisis dirinya sendiri (self eficacy) untuk menemukan dirinya sendiri, penerimaan diri atas kemampuannya sehingga timbul motivasi dalam dirinya dalam mencari solusi atas hambatan persoalan dalam pembelajarannya guna memperbaiki dirinya dalam meningkatkan kinerja dan kualitas pembelajaran secara maksimal.
\end{abstract}

Kata Kunci : Supervisi klinis, Pendekatan "PAS", Kinerja Guru

\section{PENDAHULUAN}

Surat edaran Mendikbud Nomor 36962/MPK/A/HK/2020 Pembelajaran Daring (2020) dipilih untuk mencegah penyebaran virus covid-19 kepada para siswa atau guru. Di samping itu, Mendikbud juga mengeluarkan Surat Edaran No 15 tahun 2020 tentang Pedoman Penyelenggaraan Belajar dari rumah dalam masa darurat penyebaran covid-19 (Mendikbud, 2020) tertanggal 18 Mei 2020 yang memuat: (1) pembelajaran dari rumah tetap memperhatikan protokol kesehatan; (2) pedoman penyelenggaraan belajar daring dan atau luring sebagaimana tercantum dalam lampiran yang menyampaikan penggunaan metode dan media pelaksanaan belajar di rumah.

Di tengah pandemi Covid-19, pengawas sekolah memiliki peran penting dalam mengontrol serta memastikan mutu pendidikan tetap terjaga meskipun pembelajaran PJJ. Hal ini mengharuskan pengawas sekolah tetap melaksanakan tugas pembinaan guru, kepala sekolah dan kelembagaannya secara jarak jauh agar mutu pembelajaran tidak mengalami stagnan apalagi penurunan kualitas pembelajaran dengan beradaptasi dan mengubah strategi dalam melakukan supervisi akademik dan manajeril. Permenpan RB No. 12 Tahun 2010 menyatakan bahwa Pengawas Sekolah adalah jabatan fungsional yang mempunyai ruang lingkup tugas, tanggung jawab dan wewenang untuk melaksanakan kegiatan pengawasan akademik dan manajerial pada satuan pendidikan. Dalam melaksanakan supervisi pengawas terkadang berhadapan dengan tipe (Guru Analytical Observer) yang pembelajarannya di kelas masih belum tercapai secara maksimal dan serta komitmen mengajarnya rendah, tentu hal ini apabila tidak segera ditanggulangi secara cepat akan berdampak pada kesulitan yang berkelanjutan dan bila dibiarkan tanpa ada tindakan dari pengawas/kepala sekolah selaku supervisor maka mutu pendidikan di tingkat sekolah akan menurun.

Guru (Analytical Observer), memiliki tingkat kompetensi/abstaksi tinggi tetapi tingkat komitmen rendah. Ia pandai, suka mengkritik, kemampuan bicara tinggi, mencetuskan ide-ide 
besar, tetapi Ide-idenya tak pernah /jarang terwujud. Oleh karena itu perlu adanya tindakan supervisi klinis dengan pendekatan "PAS" untuk mencari sebab kelemahan yang terjadi dalam proses belajar mengajar dan kemudian secara langsung dapat diusahakan bagaimana cara memperbaiki kelemahan tersebut. Nurtain (1989:253) mengemukakan bahwa supervisi klinis adalah suatu pembimbingan yang bertujuan untuk meningkatkan profesionalitas guru secara sengaja yang dimulai dari pertemuan awal, observasi kelas, dan pertemuan akhir yang dianalisis secara cermat, teliti dan obyektif untuk mendapatkan perubahan perilaku mengajar yang diharapkan supervisi klinis dapat untuk mencari penyebab kelemahan yang terjadi di pembelajaran.

Supervisi klinis dengan menggunakan pendekatan "PAS" merupakan akronim Persuasi, Analisis, dan Solusi. Pendekatan berarti proses antara usaha dalam rangka aktivitas penelitian untuk mengadakan hubungan dengan orang yang diteliti. Dikaitkan dengan supervisi klinis perlunya pendekatan dalam rangka membangun hubungan guru dan supervisor sebagai mitra kerja. Selanjutnya Persuasi adalah proses komunikasi yang mengajak atau membujuk orang lain dengan mengubah tujuan sikap, keyakinan dan pendapat sesuai keinginan komunikator. Pada definisi ini 'ajakan' atau 'bujukan' adalah unsur tanpa paksaan/ancaman, (Burgon\&Huffner,2002) berarti membujuk secara halus supaya menjadi yakin.

Ajakan kepada seseorang dengan cara memberikan alasan dan prospek baik yang meyakinkannya. Pendekatan persuasi dalam supervisi ini berarti mengajak secara halus kepada guru yang mengalami permasalahan dalam pembelajaran dengan cara memberikan alasan dan prospek baik yang meyakinkan sehingga mereka mau meningkatkan kemampuan dan ketrampilan mengajarnya. Persuasi dilakukan agar guru analytical observer dirinya merasa nyaman, tidak dicari cari kesalahan guru oleh supervisor, tetapi pembinaan dilakukan pengawas lebih bersifat ramah lebih terarah sebagai pendampingan dalam usaha guru meningkatkan perbaikan sistem pembelajarannya dengan analisa masalahnya dalam pembelajaran dengan melakukan komunikasi yang efektif. Melalui pesan komunikasi dapat diartikan bahwa individu sedang mengalami proses belajar tentang dunia dan orang lain,menjadi siapa, dihibur, dibujuk, bergurau, ditipu atau diberi informasi (Stewart \&Ruben,2013:17)

Analisis menurut Suharso dan Ana Retnoningsih (2005) adalah penyelidikan terhadap suatu peristiwa(karangan,perbuatan dan sebagainya) untuk mengetahui keadaan yang sebenarnya(sebab musabab, duduk perkara dan sebagainya).Dalam supervisi ini untuk menyelidiki penyebab persoalan dalam pembelajaran yang dialami guru tidak bisa optimal dalam pembelajarannya agar guna mendapatkan strategi solusi yang tepat.

Solusi berarti penyelesaian/pemecahan masalah. Menurut Evans (1994) problem solving diartikan sebagai aktivitas yang dihubungkan dengan cara penyelesksian yang cocok untuk tindakan mengubah suasana sekarang menjadi suasana yang dibutuhkan. Artinya setiap tahapan penyelesaian masalah dibutuhkan sebuah filter dalam menentukan cara yang baik untuk menyelesaikan masalah tersebut. Dengan menyaring berbagai persoalan yang ada, seseorang akan mudah dalam melakukan proses pemecahan masalah dari berbagai masalah yang dihadapai guru (analytical observer) dalam komitmen pembelajaran untuk memperbaiki pada pembalajaran berikutnya.

\section{METODE PENELITIAN}

Penelitian Tindakan kepengawasan (PTKp) Supervisi klinis menggunakan pendekatan penelitian deskriptif kualitatif. Penelitian kualitatif adalah penelitian yang bermaksud memahami fenomena tentang apa yang dialami oleh subyek penelitian misalnya perilaku, persepsi, motivasi, tindakan, dan lain-lain, secara holistik, dan dengan cara deskripsi dalam bentuk kata-kata dan bahasa, pada suatu konteks khusus yang alamiah dan dengan memanfaatkan berbagai metode alamiah ( Moloeng, 2004:6).

Karakteristik pokok pendekatan kualitatif ini mementingkan makna, konteks dan perspektif emik,proses penelitian lebih berbentuk mementingkan kedalaman dari pada keleluasaan cakupan penelitian (Sarjono,2006:49). Desain penelitian ini adalah mengarah pada 
penelitian etnografi. Metodologi penelitian etnografi merupakan prosedur yang menghasilkan data deskriptif. Inti dari etnografi adalah upaya memperhatikan makna-makna tindakan dari kejadian yang menimpa orang yang ingin kita pahami.

Sumber data utama dalam penelitian kualitatif ini adalah kata-kata dan tindakan selebihnya adalah data tambahan seperti dokumen dan lain-lain. Sumber data etnografi adalah nara sumber (informan), peristiwa (aktivitas), tempat (lokasi), benda atau rekaman, dokumen dan arsip ( Sutopo, 2002:50).

Sumber data dalam penelitian ini meliputi nara sumber dan dokumen. Nara sumber data berupa manusia ( Sutopo, 2002:50) Nara sumber dalam penelitian ini adalah informan kunci yang ada di Madrasah Binaan Kecamatan Bringin Kabupaten Semarang. Nara sumbernya adalah 13 Guru tipe Analytical observer 13 madrasah, karena beliaulah yang mendapatkan supervisi klinis. Metode pengumpulan data dilakukan dengan wawancara, observasi dan dokumentasi,Teknik analisis data dilakukan dengan metode interaktif yang terdapat dalam tiga kegiatan utama yang saling berkaitan dan terjadi secara bersamaan yaitu reduksi data, penyajian data dan penarikan kesimpulan atau verifikasi.

\section{HASIL DAN PEMBAHASAN}

\section{Supervisi Klinis}

Istilah supervisi klinis diadopsi dari istilah kedokteran dengan asumsi dan harapan keakraban yang terjadi anatar dokter dengan pasien dapat pula diterapkan dalam pelaksanaan supervisi yaitu terjadi pola komunikasi yang baik dan akran antara guru dengan pengawas. Dalam hal ini maka pengawas menggunakan pendekatan persuasi yang berarti membujuk secara halus supaya menjadi yakin dengan cara memberikan alasan dan prospek yang baik sehingga guru mau meningkatkan kemampuan dan ketrampilan mengajarnya.

Supervisi klisnis diartikan pertemuan tatap muka antara supervisor dan guru, membahas tentang hal mengajar di dalam kelas guna perbaikan pembelajaran dan pengembangan profesi dengan cara kolegial atau kesejawatan antara supervisor dengan guru ( sergiovanni,1997). Pernyataan tersebut dipertegas oleh Snyder\&Anderson (dalam Sagala 2010) yang mengatakan Supervisi klinis adalah suatu teknologi perbaikan pembelajaran, tujuan yang ingin dicapai, dan memadukan kebutuhan sekolah dengan pertumbuhan. Selanjutnya Cogan (dalam Sagala,2010) mengartikan supervisi klinis sebagai upaya yang dirancang secara rasional dan praktis untuk memperbaiki performansi guru di kelas dengan tujuan untuk mengembangkan profesionalitas guru dan perbaikan pengajaran.

Untuk memperbaiki performansi guru maka perlu diadakan Analisis penyelidikan yang mendalam terhadap suatu peristiwa (karangan, perbuatan, dan sebagainya) untuk mengetahui keadaan yangsebenarnya (sebab musabab, duduk perkara dan sebagainya). Dalam supervisi klinis ini untuk menyelidiki penyebab persoalan dalam pembelajaran yang dialami guru (analytical observer) tidak bisa maksimal dalam pembelajarannya guna mendapatkan solusi (problem solving) atau pemecahan masalah secara yang tepat dalam melakukan perbaikan pembelajaran berikutnya.

\section{Tujuan Supervisi Klinis}

Supervisi klinis bertujuan untuk menjamin kualitas pelayanan belajar secara berkelanjutan dan konsisten. Selain itu supervisi klinis bertujuan untuk memperbaiki performansi guru dalam proses pembelajaran dan membantu siswa mengatasi masalah pembelajaran secara efektif.

Berliner dan Tilmnoff ( dalam Sagala 2010) menyatakan tujuan supervisi klinis untuk mengefektifkan proses pembelajaran guru di kelas dengan upaya : (1) memberikan reaksi secara konstruktif terhadap emosi dan perbuatan, (2) aktif mendengarkan apa yang dikatakan, dibaca dan dilaksanakan siswa, (3) memberikan arahan dan peringatan kepada siswa dengan terus mengawasi, (4) tampil dengan percaya diri dalam menyajikan materi, (5) mengikuti perkembangan siswa secara teratur dan mempertimbangkan langkah-langkah perbaikan, (6) 
Menampilkan ekspresi positif , kebahagiaan, perasaan dan emosi yang positif, (7) mendukung siswa untuk berani bertanggungjawab atas kelas mereka sendiri, dan (8) menyiapkan siswa untuk belajar dengan baik. Anderson dan Gall (1987) yang dikutip Sagala (2010:200) menyatakan tujuan supervisi klinis adalah : (1) pembelajaran yang efektif dengan menyediakan umpan balik, (2) dapat memecahkan permasalahan, (3) membantu guru berperilaku baik sebagai upaya pengembangan profesionalitas guru.

\section{Tahapan Supervisi Klinis}

Terdapat tiga episode atau tahapan dalam pelaksanaan supervisi klinis , yaitu : (1) Tahap Pertemuan Awal, (2) Tahap Observasi Kelas, dan (3) Tahapan Pertemuan Balikan.

1) Tahap pertemuan Awal : a. Supervisor dan guru menciptakan suasana yang akrab untuk menghindari beban psikologis, b. Target tahapan ini adalah terjadinya kesepakatan atau kontrak berkaitan dengan pembinaan guru, c. Langkah-langkahnya adalah : Supervisor menyampaikan laporan kepada guru (analytical observer) dalam suasana kolegial sehingga guru mau terbuka terhadap masalah yang dihadapi. Guru bersama supervisor membahas rencana pembelajaran yang disepakati untuk dikaji serta dikenali ketrampilan mengajarnya dengan mengembangkan instrumen yang akan dipakai sebagai panduan dalam mengobservasi penampilan mengajarnya.

2) Tahap Observasi Kelas : a. Pengawas bersama guru memasuki ruang kelas dengan penuh keakraban, diruang kelas. Kemudian guru dipersilahkan masuk ke Google Class, Supervisor sebagai Co Teacher . b. Guru memberikan penjelasan kepada siswa maksud kedatangan supervisor. melalui Google Meet, c. Supervisor mengobservasi penampilan guru mengajar melalui syncronus a syncronus pembelajaran guru dengan Google Meet, menampilkan materi dengan share screen, diakhiri penilaian dengan Google form yang telah dibuat guru, supervisor mengamati pelaksanaan tersebut dengan menggunakan format observasi yang telah disepakati. d. Selama pengamatan pengawas hanya menfokuskan pada kontrak kesepakatan dengan guru. Jika ada hal-hal yang penting diluar kontrak, supervisor dapat mebuat catatan untuk didiskusikan atau pembinaan selanjutnya. Setelah pembelajaran selesai , guru bersama-sama dengan supervisor menuju ruangan khusu untuk tindak lanjut.

3) Tahap Pertemuan Balikan. a. Supervisor memberikan penguatan pada guru tentang proses pembelajaran yang baru dilaksanakan. b.Supervisor dan guru memperjelas kontrak yang dilakukan mulai dari tujuan sampai pelaksanaan evaluasi.c. Supervisor menunjukkan hasil observasi berdasrkan format yang disepakati. d. Supervisor menanyakan tanggapan perasaannya atas hasil observasi tersebut. G. Supervisor dan guru membuat kontrak pembinaan berikutnya.

\section{Kinerja Guru}

Menurut Priansa (2014) menyatakan bahwa " tingkat keberhasilan guru dalam melaksanakan dan menyelesaikan pekerjaan utamanya sebagai guru adalah "level of performance". Secara tegas priansa menyebutkan bahwa level of performance atau tugas utama guru utama adalah mendidik, mengajara, membimbing, mengarahkan, melatih , menilai dan mengevaluasi proses belajar peserta didiknya. Secara teknis tugas guru tersebut dituangkan dalam perencanaan pelaksanaan pembelajaran, proses pelaksaan pembelajaran, dan pelaksanaan evaluasi atau penilaian pembelajaran.

Dari uraian diatas, guru sebagai tenaga pendidik dituntut agar bisa memiliki kinerja yang baik. Kinerja guru sering menjadi tumpuan dalam mencapai harapan kualitas lulusan lembaga pendidikan. Maka kehadiran guru dalam proses belajar mengajar menjadi peranan penting bagi seorang guru.

Saud ( 2011) menyatakan bahwa dalam sistem pendidikan dan pembelajaran dewasa ini kehadiran guru sangat penting dalam proses belajar mengajar. Peran guru dalam proses belajar mengajar belum dapat digantikan sekalipun oleh komputer yang paling modern. masih tetap memegang peranan . oeh karena itu kinerja guru juga bukan hanya dilihat dari kemampuan 
dalam menciptakan suasana pembelajaran yang bermakna, menyenangkan, kreatif, dan dialogis melainkan juga dilihat dari komitmennya yang tinggi terhadap peningkatan prestasi peserta didik. Komitmen yang dimaksud ialah daya dorong dari dalam diri setiap guru untuk tetap bersedia belajar dan melaksanakan tugas yang dipercayakan kepadanya dengan sebaikbaiknya dan penuh rasa tanggung jawab.

Dalam menentukan trategi supervisi, supervisor akan mudah memilih strategi supervisi yang tepat dengan mengetahui perilaku guru, karena kesalahan superrvisor dalam memilih strategi, supervisi tidak akan efektif kurang bermakna. Berdasarkan komitmen dan tanggung jawab guru terdapat empat model perilaku guru yaitu teacher drop out, unfocused worker, analytical observer, dan profesional dengan ciri-ciri sebagai berikut : (1) Guru (Droup Out), memiliki tingkat komitmen rendah dan tingkat abstraksinya rendah. Menghadapi guru seperti ini supervisor menggunakan pendekatan direktif, (2) Guru (Unfocused Worker)/ guru yang kerjanya tak terarah, memiliki tingkat komitmen kerjanya tinggi tapi tingkat berfikirnya rendah, pendekatan supervisi yang bisa diterapkan Collaborative, (3) Guru yang pengamat analisis (Analytical Observer) tingkat abstraknya tinggi tetapi rendah komitmennya rendah, pendekatan yang tepat tingkat berfikirnya rendah, strategi supervisi yang bisa diterapkan Collaborative, , (4) Guru profesional yaitu memiliki komitmen tinggi dan abstraksi tingi, strategi pendekan supervisi nondirective.

\section{Tugas Pengawas Dalam Supervisi Klinis}

Peran supervisi klinis pengawas dengan pendekatan PAS bagi guru binaan analytical observer Madrasah Ibtidaiyah Kec. Bringin Kab. Semarang Jawa Tengah dalam mengatasi permasalah komitmen kinerja serta hambatan pembelajaran yang dialami guru dalam melaksanakan pembelajaran. Permasalahan yang disupervisi klinis ini menyangkut masalah internal guru seperti semangat mengajar, motivasi dan kondisi kehidupan guru yang mempengaruhi tugas mengajar, juga menyangkut masalah ekternal guru yang dipicu oleh kurang mampunya guru dalam menyelenggarakan kegaiatan belajar mengajar.

Dalam pengelolaan supervisi klinis memang tidak begitu mudah berjalan karena sifat supervisi klinis bersifat individu dan personal sehingga banyak guru memilih untuk tidak menjalani supervisi klinis. Perlu kita sadari betapa perlunya supervisi klinis bagi pengembangan komitmen kemampuan mengajar guru dalam pembelajaran. Sebagaimana uraian diatas peran pentingnya supervisi klinis adalah menekankan pada peran membantu, melayani, dan membina guru dengan maksud untuk meningkatkan kulitas kemampuan guru dalam mengajar (Saiful Sagala,2010:194).Dengan demikian Supervisi klinis Pengawas dengan pendekatan PAS peran dan fungsinya untuk membantu, melayani , membina guru analytical observer untuk meningkatkan kemampuan kompetensinya sehingga guru tersebut lebih mudah menyelesaikan permasalahan yang dihadapi selama mengajar, selain itu juga membantu guru untuk memperbaiki dan meningkatkan kualitas belajar mengajar.

\section{Hasil Temuan}

Supervisi klinis seperti yang diuraikan diatas tersebut akanmempunyai peran yang penting bagi peningkatan performansi kinerja guru serta meningkatkan komitmen guru dalam mengembangkan kemampuan mengajar guru.

Hasil temuan penelitian menunjukkan bahwa peran supervisi klinis dengan pendekatan PAS yang dilakukan pada guru di binaan Madrasah Ibtidaiyah Kec. Bringin Kab. Semarang Jawa Tengah adalah untuk mengatasi permasalahan komitmen kinerja yang dialami oleh guru dalam melaksanakan kegiatan belajar mengajar. Permasalahan yang di supervisi klinis ini menyangkut internal guru (analytical observer) seperti semangat mengajar, motivasi dan kondisi kehidupan guru yang mempengaruhi tugasnya mengajar, juga menyangkut masalah eksternal guru yang dipicu oleh kurang mampu guru menyelenggarakan kegiatan belajar mengajar secara maksimal. 
Pendekatan supervisi klinis yang dilakukan pada guru dengan diagnosa analisis kemampuannya dapat menumbuhkan self-efficacy sebagai keyakinan individu dalam kemampuan mereka untuk memobilisasi motivasi, sumber daya kognitif, dan lembaga untuk melakukan kontrol atas peristiwa tertentu (Hammil,2003), sehingga guru termotivasi untuk selalu berusahalebih baik dalam merancang kegiatan belajar mengajar yang akan dilaksanakan. Selain itu juga guru mampu mempersiapkan diri agar tampil dalam mengajar dan menilai dengan tepat serta bertanggungjawab atas tugasnya.

Bass \& Avolio (1997) menyatakan bahwa pemimpin berperilaku orientasi hubungan akan dapat merpertinggi persepsi para pengikut mengenai Self-eficacy ( kepercayaan diri maupun potensi perkembangannya). Dengan demikian Self-eficacy dalam dunia pendidikan akan mempengaruhi hubungan antara perilaku pimpinan (pengawas/kepala sekolah) berorientasi hubungan dengan kinerja yang diharapkan dari bawahan. Dengan adanya pemberdayaan psikologis (psychological enpowerment) mampu mempengaruhi kinerja guru tipe (Analytical observer).

Adanya berbagai studi yang mendukung Self-eficacy dan komitmen organisasi semakin memperkuat keyakinan peneliti bahwa dengan pendekatan PAS mampu menumbukan mengembangkan Self-eficacy guru berorientasi pada komitmen hubungan kerja sekolah dan tugas pembelajaran. Selanjutnya Jermier \& Berkes (1979) mengemukakan bahwa pegawai yang diberi kesempatan untuk berpartisipasi dalam pengambilan keputusan akan memiliki tingkat komitmen yang lebih besar terhadap organisasi. Hasil penelitian menunjukkan bahwa para supervisor yang suka membantu dan memberikan dukungan emosional didapati mampu memberikan pengaruh terhadap komitmen mereka pada organisasi (Brown,2003)

Adapun cara menumbuhkan Self-eficacy guru (Analytical observer) yang dilakukan supervisor dalam supervisi klinis pendekatan PAS adalah sebagai berikut :

1. Membangun Keasadaran diri tentang tugas dan tanggungjawabnya, bahwa mereka memiliki peran yang sangat penting dalam mengembangkan pribadi peserta didik. Harus disadari bahwa pengembangan pribadi peserta didik merupakan proses penyiapan generasi bangsa, sehingga bangsa ini menjadi bangsa yang bermartabat, bersaing dan bersanding dengan negara-negara lain.

2. Meningkatkan Pemahaman, setelah memiliki keadaran yang tingi tentang tugas dan fungsinya, langkah berikutnya adalah meningkatkan pemahaman guru agar mau melaksanakan tugas dan fungsi sebagai guru dengan bik dan efektif sesuai dengan standar kompetensi guru.

3. Menumbuhkan Kepedulian, agar guru peduli terhadap peserta didik dan lingkungan sekolah, dengan sikap positif dalam menjalankan tugas pokok dan fungsinya sebagai pengajar.

4. Membangun komitmen yang tinggi dalam diri guru sebagai kontrak sumpah janji untuk mengabdikan diri dan mengemban tugas tanggungjawab dalam dunia pendidikan. Dengan demikian guru merasa aman , nyaman dan menyenangkan dalam mengemban tugasnya.

Berdasarkan faktor diatas pengelolaan supervisi klinis akan menunjang kemampuan secara individu dan lebih mendasar dalam membantu guru dalam melaksanakan tugasnya. Melalui pengelolaan optimalisasi pendekatan supervisi klinis secara optimal dalam mendukung guru madrasah menjalankan tugas pembelajaran sesuai tujuan visi misi madrasah yang telah ditetapkan.

Sahertian,2000:134 menegaskan bantuan yang yang dapat diberikan pada guru terkait dengan kegiatan supervisi klinis pada guru adalah bantuan :

1. Merancang progam belajar mengajar dengan baik.

2. Melaksanakan proses belajar mengajar dengan baik

3. Menilai proses hasil belajar.

4. Mengembangkan manajemen kelas.

Pada pelaksanaan supervisi klinis ini proses pemberian bantuan guru sebagai bekal dalam menjalankan tugasnya diarahkan kepada peningkatan kemampuan guru secara mandiri dalam 
mengatasi permasalahan yang dihadapi selama pembelajaran, serta mengembangkan komitmen guru dalam mengembangkan kompetensi pedagogik berdasarkan kemampuan yang dimiliki guru.

Adapun hasil temuan penelitian dilapangan tentang penelitian tindakan supervisi klinis dengan pendekatan PAS di Madrasah Ibtidaiyah binaan Kec. Bringin Kab. Semarang Jawa Tengah sebagai berikut :

1) Pengelolaan supervisi klinis dilakukan secara terprogam dan sistimatis,

2) Pengelolaan supervisi klinis telah memenuhi sifat supervisi klinis yang kreatif, ekploratif,inovatif, dan terbuka,

3) Ruang lingkup pengelolaan supervisi klinis ini dibatasi pada komitmen kinerja guru (Analytical observer), motivasi mengajar guru, pengelolaan pembelajaran dan pengelolaan kelas, pengembangan dan penguasan materi pembelajaran,

4) Memenuhi prinsip supervisi klinis yang ditunjukkan dengan supervisi klinis berjalan sesuai dengan prinsipnya,

5) Supervisi klinis dapat memberikan solusi/pemecahan masalah yang terlihat guru lebih fokus dan terarah berdasarkan persoalan permasalahan yang dihadapi guru (Analytical observer),

6) Setelah mendapatkan tindakan kepengawasan melalui supervisi klinis pendekatan PAS, kondisi guru (Analytical observer) terjadi adanya peningkatan kinerjanya lebih baik, terbukti dengan adanya komitmen tanggungjawab guru dalam melaksanakan tugasnya, mampu menyelesaikan baik masalah internal dan ekternal hambatan permasalahan yang dihadapi dengan keinginannya sendiri tanpa ada paksaan dari pihak lain dalam memperbaiki pembelajarannya. Hal ini dikarenakn guru (Analytical observer) selama mengikuti supervisi klinis pendekatan PAS ini tidak merasa tertekan , atau dicari-cari kesalahanya, melainkan hubungan yang terbangun atas kemitraan dan kolaborasi dalam supervisi anatara guru dan pengawas, tetapi malah mendapatkan solusi dan menciptakan Self-eficacy yang kuat bagi guru untuk menganalisis persoalan pemasalan, hambatan dalam memecahkan persolan dengan solusi yang tepat.

\section{Hambatan dan Solusi}

Hambatan yang berhubungan dengan pengelolaan supervisi klinis pendekatan PAS berdasarkan temuan peneliti dilapangan adalah :

1. Guru yang disupervisi klini pertamakali nampak merasa malu untuk dilakukan supervisi klinis dan protes dengan mengkritik adanya supervisi klinis pengawas, apalagi pandangan sebagian guru terhadap supervisi klinis ini pastilah guru yang memiliki kesalahan berat yang membuatnya perlu disupervisi klinis.Selama mengikuti supervisi klinis guru (Analytical observer) belum bisa bersikap terbuka untuk mengungkapkan persoalanya berkaitan dengan permasalahan yang dihadapinya sehingga pengawas mengarahkan untuk dapat lebih terbuka.

2. Masih ditemui guru dalam supervisi klinis yang terlambat mengikuti kegitan pelaksanaan dengan berbagai alasan dan dalam mengikuti supervis klinis kadang kurang fokus pada kegiatan yang dilakukan, kurang memahami penjelasan yang diberikan supervisor.

Dari penjelasan hambatan diatas ada beberapa cara peneliti dalam mengatasi masalah tersebut yaitu :

1) Peneliti menggunakan pendekatan persuasi dalam memberikan penjelasan dan pengertian tentang manfaat pada guru (Analytical observer) yang disupervisi klinis akan lebih baik kemampuannya dalam mengatasi permasalah atau hambatan dalam kinerja maupun pembelajarannya. Dimana guru akan mendapatkan bantuan bimbingan dan arahan dengan mengotmalkan kemampuan dirinya untuk mengatasi permasalahannya dalam proses pembelajaran, hal ini akan meningkatkan kinerjanya. Setelah pendekatan persuasi tersebut . Setelah ada pendekatan persuasi mereka merasa bergembira adanya supervisi klinis sebagai solusi dan pencerahan dalam menyelesaikan hambatan pembelajaran selama ini. Apalagi untuk menghindari rasa malu yang dianggap oleh sebagian guru bahwa supervisi klinis 
dilakukan bagi yang mempunyai pelanggaran berat dapat dijembatani dengan menggunakan G-suite for education platform Google Class Room dalam pembinaanya.

2) Dalam melaksanakan supervisi klinis menggunakan pendekatan persuasi sehingga terjalin hubungan komunikasi yang harmonis sebagai mitra kerja menumbuhkan sikap terbuka guru untuk mengungkapkan persoalannya sebagai mitra kerja sehingga guru dapat merasa nyaman untuk mampu mengungkapkan permasalahan yang tengah dihadapi secara menyeluruh, hambatan dalam kinerja maupun dalam permasalahan kegiatan pembelajaran yang belum optimal untuk dianalisas dengan membangun hubungan kolaborasi guru dan pengawas dalam mencari solusi bersama.

Kedekatan hubungan pengawas dengan guru sangat diperlukan untuk mengurai permasalahan secara terbuka bagi guru yang mengalami permasalahan, semakin terbuka jelas duduk persoalan yang dihadapi maka semakin mudah cara untuk mengatasinya permasalahanya.

Hal senada dikuatkan Johson,1974 bahwa keefektifan kemitraan tergantung pada kemampuan " saling menghargai dan saling memperhatikan, bukan basa basi,tetapi saling menyadari dan memahami keberadaan masing masing dari segi karakter seperti ramah, cakap, suka bingung, punya kelemahan dan berwaswasan luas".

Sedangkan Dewey yang dikutip (Jhonson,1974) mengatakan " faktor komunikasilah yang paling mengagumkan dan buah komunikasi adalah partisipasi serta saling memberi dan menerima sebagai suatu keajaiban yang ada bandingannya". Dengan demikian kegiatan supervisi mutlak memerlukan kemitraan antara supervisor dan guru dalam berbagai aspek kegiatan. Tanpa kemitraan dan saling keterbukaan yang dilandasi komunikatif secara informal mustahil kegiatan supervisi dapat terlaksana dengan efektif.

3) Memberikan motivasi dengan menganalisis permasalahan dengan pendekatan psychologis tentang Self-eficacy ( kepercayaan diri maupun potensi perkembangannya) agar lebih tahu arti tentang dirinya sendiri untuk lebih fokus pada kegiatan supervisi klinis yang sedang diikutinya dengan unsur penegasan bahwa kegiatan supervisi ini memberikan dampak yang optimal apabila guru fokus menjalaninya. Hal ini juga dikuatakan tentang (Self eficacy). Dengan demikian dalam memotivasi perlu ucapan yang posistif diperluka dalam supervisi klinis sebagai umpan balik terhadap kinerja guru sebagaimana ditekan oleh Neagly dan Evans (1980) bahwa setelah observasi kelas seorang guru yang menyadari kinerjanya baik berharap mendapatkan pujian dari pengawas untiuk membangkitkan semangat guru meningkatkan kemampuan pembelajarannya.Pendapat ini juga didukung Baumaster (dalam Bradler et al ,2012) menyatakan pujian akan mempengaruhi kinerja sesorang baik ataupun buruk.

Dalam pengelolaan supervisi klinis memang tidak begitu mudah berjalan karena sifat supervisi klinis bersifat individu dan personal sehingga banyak guru memilih untuk tidak menjalani supervisi klinis. Perlu kita sadari betapa perlunya supervisi klinis bagi pengembangan komitmen kemampuan mengajar guru dalam pembelajaran. Sebagaimana uraian diatas peran pentingnya supervisi klinis adalah menekankan pada peran membantu, melayani, dan membina guru dengan maksud untuk meningkatkan kulitas kemampuan guru dalam mengajara ( Saiful Sagala,2010: 194). Dengan demikian Supervisi klinis Pengawas dengan pendekatan PAS, peran dan fungsinya untuk membantu, melayani, membina guru (analytical observer) untuk meningkatkan kemampuan kompetensinya sehingga guru tersebut lebih mudah menyelesaikan permasalahan yang dihadapi selama mengajar, selain itu juga membantu guru untuk memperbaiki dan meningkatkan kualitas belajar mengajar.

\section{KESIMPULAN}

1. Peran supervisi klinis pengawas dengan pendekatan PAS bagi guru binaan analytical observer Madrasah Ibtidaiyah Kec. Bringin Kab. Semarang Jawa Tengah dalam mengatasi permasalah komitmen kinerja serta hambatan pembelajaran yang dialami guru dalam melaksanakan pembelajaran. Permasalahan yang disupervisi klinis ini menyangkut masalah 
internal guru seperti semangat mengajar, motivasi dan kondisi kehidupan guru yang mempengaruhi tugas mengajar, juga menyangkut masalah ekternal guru yang dipicu oleh kurang mampunya guru dalam menyelenggarakan kegaiatan belajar mengajar.

2. Pengelolaan supervisi klinis yang dilakukan oleh supervisor selaku peneliti diantaranya : a) Pengelolaan supervisi dilakukan secara terprogram, dimana pembuatan program supervisi klinis dilakukan secara sistematis, b) Pengelolaan supervisi klinis memenuhi sifat supervisi klinis kreatif, terbuka, inovatif dan juga ekploratif, c) Ruang lingkup pengelolaan supervisi klinis dibatasi pada pengelolaan pembelajaran dan pengelolaan kelas, pengembangan materi dan penguasaan materi serta motivasi pengajaran guru, d) Supervisi klinis memenuhi prinsip supervisi klinis hal itu menunjukkan bahwa supervisi akan berjalan sesuai dengan prinsipnya, e) Supervisi klinis memberikan pemecahan masalah pada guru, hal ini tampak lebih terarah mengacu pada permasalahan yang dihadapi oleh guru, f) Kondisi guru setelah mendapatkan supervisi klinis adalah terlihat baik dan membuat guru mampu menyelesaikan permasalahan yang dihadapinya dengan keinginannya sendiri bagi guru binaan Madrasah Ibtidaiyah Kec. Bringin Kab. Semarang Jawa Tengah dalam mengatasi permasalahan komitmen kinerja serta hambatan pembelajaran yang dialami guru analytical observer dalam melaksanakan kegiatan pembelajaran.

\section{DAFTAR PUSTAKA}

Ana Retnoningsih dan Suharso. (2005). Kamus Besar Bahasa Indonesia. Semarang: Widya Karya

Bass, B. \& Avalio, B. (1997). Full range leadership development:Manual for multifactor leadership questonaire. Redwood City, California: Mind Garden.

Bass,B.M, Avalio,B. Bradler,C.et al. (2012). Employee Recognition and Performance-Filed Experiment".Draf.

Burgon \& Huffner. (2002). Human Comunication.London: Sage Publication.

Evans, Jame R. (1994). Berfikir Kreatif, dalam Pengambilan Keputusan Manajemen. Jakarta : Bumi Aksara

Hammil, S. K. (2003). Resilience and self-efficacy: The importance of efficacy beliefs and coping mechanisms in resilient adolescents. Colgate university Journal of The Sciences, 115-146.

Jermier, J. \& Berkes, L. (1979). Leader behaviour in police command bureaucracy: A closer look at the quasi-military model.Administrave Science Quaterly,24,1-24

Miles, M. B, \& Huberman, M. A. (1994). Qualitative data analysis: an expanded sourcebook (2rd ed). London: Sage Publication.

Neagley, R. L dan Evans, N. D. (1980). Handbook for Effective Supervision of instruction. Englewood Cliffs, N. J: Prentice-Hall,inc.

Nurtain. (1989). Supervisi Pengajaran ( Teori dan Praktek). Jakarta: Depdikbud Dirjen Dikti.

Piet, A. S. (2000). Konsep Dasar dan Teknik Supervisi Pendidikan. Jakarta: Alfabeta.

Priansa, D. J. (2014). Kinerja Profesionalisme Guru. Bandung: Alfabeta

Sa'ud, U.S. (2010). Pengembangan Profesi Guru. Bandung: Alfabeta

Sagala,S. (2010). Supervisi Pembelajaran Dalam Profesi Pendidikan. Bandung: Alfabeta

Stewart, Lea P, dan Brent D. Ruben. (2006). Komunikasi Perilaku Manusia. Edisi ke Lima. Jakarta: PT Raja Grafindo Persada

Sutopo, H.B. Metode Penelitian Kualitatif Dasar dan Terapannya Dalam Penelitian. Surakarta : Sebelas Maret University Press. 